\title{
Assessment of Dissolved Heavymetal Pollution in Five Provinces of Zambia
}

\author{
Kabunga Nachiyunde ${ }^{1}$, Hideo Ikeda ${ }^{1}$, Tetsuji Okuda ${ }^{2}$, Wataru Nishijima ${ }^{2}$ \\ ${ }^{1}$ Graduate School for International Development and Cooperation, Hiroshima University, Kagamiyama, Higashihiroshima, Hiroshi- \\ ma, Japan; ${ }^{2}$ Environmental Research and Management Centre, Hiroshima University, Kagamiyama, Higashi-Hiroshima, Hiroshima, \\ Japan. \\ Email: bungman@live.jp
}

Received 2013

\begin{abstract}
Zambia's economy is hinged on mining activities with $\mathrm{Cu}$ being the main metal. $\mathrm{Zn}$ and $\mathrm{Pb}$ were mined at one point in Kabwe town. There are also known deposits of Co and Mn. The study focused on comparing heavy metal pollution from different regions across Zambia with a view of determining the impact of the stage of social development and economic activities on the environment. The water analysed was obtained near dump sites,farmlands, pit latrines, water reservoirs or dams, major rivers and small streams that traverse Lusaka city and towns in the Copperbelt,and water from several public taps. Analysis revealed that Mn was the largest pollution factor study areas; groundwater both near illegal dumpsites and on-site sanitation facilities did not reveal any severe pollution problems beyond drinking water permissible values $(P V)$. Furthermore, principal component analysis (PCA) and Pearson correlation ( $r$ ) found a strong correlation between $\mathrm{Mn}$, and the two metals - $\mathrm{Cu}$ and $\mathrm{Ni}$ at $r=0.632 \mathrm{and} r=0.676$ respectively. The other parameters (Cd, Cr, $\mathrm{As}, \mathrm{Zn} \& \mathrm{~Pb}$ ) were not a significant factor in explaining the dissolved metal pollution in Zambia.
\end{abstract}

Keywords: Heavy Metals; Manganese Pollution; Copper Mining

\section{Introduction}

In Zambia, there is a well-developed mining sector which is the backbone of the economy. The mining sector is dominated by $\mathrm{Cu}$ and Co production. The country is also among the major producers of gem-quality emerald, a variety of mineral commodities for the construction industry, and other gemstones (primarily amethyst, beryl, aquamarine and tourmaline) and has a high potential of coal production [1].

There is an effort to decrease to a minimum or eliminate penetration of the most serious contaminants into the food chain and therefore also into the human body. One of the tool in this struggle is to target the monitoring of relevant contaminants in raw materials and foods of animal origin and water which is the main component utilised by plants. In order to do this, the study focused on a wide area of Zambia spanning five provinces and analysing water samples from 74 sites. Dissolved metal analysis was the focus of the study because the concentrations of metals in dissolved form are also readily available for absorption by plants, and direct intake by animals.

Most of the published work in Zambia about pollution has to a large extent been confined to study of heavy metals in food, soils and sediments [2-5]. There are high incidences of pathogens such as typhoid, cholera, streptococci, salmonella, poliomyelitis, and protozoans; in fact many cholera outbreaks have been reported over the past years and from as early as 1977[6], as a result, heavy metal contamination has largely been ignored in Zambia (e.g. by the media) although the scientific community makes occasion effort to determine heavy metal loadings in different environments (water, sediments/soil) [7].

\subsection{Description of the Study Areas by Province}

\subsubsection{Kabwe town (Central Province)}

Kabwe, in central Zambia, is located about 150 kilometres north of the nation's capital, Lusaka, and was Zambia's thriving industrial base. In 1902, rich deposits of Zn and $\mathrm{Pb}$ were discovered there. Mining and smelting commenced thereafter and continued until 1994 without addressing the potential dangers of $\mathrm{Pb}$ contamination. $\mathrm{Cd}$ and Ag were also produced as by-products. The mine and smelter are no longer operating but have left a city poisoned and scared by debilitating concentrations of $\mathrm{Pb}$ dust in the soil. In one study conducted in Kabwe, the dispersal in soils containing $\mathrm{Pb}, \mathrm{Cd}, \mathrm{Cu}$, and $\mathrm{Zn}$ extended over a $20 \mathrm{~km}$ radius at levels much higher than those 
recommended by the World Health Organization [5].

Mining is Zambia's economic lifeblood, but Kabwe's mining activitiesceased in 1994, when heavy financial losses forced the state-run Zambia Consolidated Copper Mines (ZCCM) company to shut down operations. Once was Africa's largest and richest mining town, Kabwe was left with a legacy of toxic waste.

\subsubsection{Solwezi (North Western Province)}

Solwezi is the capital of the North Western Province of Zambia. The district had approximately 239,051 inhabitants as shown bythe 2010 census [8]. The main industry in Solwezi is Cu mining at Kansanshi Mine located about $10 \mathrm{~km}$ north, and Lumwana Mine located about $65 \mathrm{~km}$ west out of the town centre, run by First Quantum Minerals and Equinox Minerals respectively.

Kansanshi Mine exploits $\mathrm{Cu}-\mathrm{Au}$ ore from Kansanshi Anticlinal. The mining site has been in operation since 19th century for $\mathrm{Cu}$ and Au successively. Lumwana on the other hand was discovered in 1961, no serious work was carried out there until Equinox Minerals Ltd became involved in 1999.

The water from this region was sampled and analysed for dissolved heavy metal pollution. It is our proposition that it will be in the best interest of the Zambian government to carry out a similar, independent, study in the same area after some years of sustained mineral exploration because Solwezi is home to some of the newest mines in the country and negative environmental effects may not have reached their climax yet.

\subsubsection{Mazabuka District and its Satellite Town of Magoye (Southern Province)}

Mazabuka and Magoye are predominantly agricultural towns. In Zambia, fertilizer application primarily follows a blanket recommendation. Historical evident exists that continued fertilizer use without guided recommendation and lack of proper soil management resulted in declining soil productivity. A soil fertility survey was carried out in 2001 in Eastern, Central and Southern Provinces of Zambia whose objective was to prepare fertilizer recommendations based on soil analysis for use by farmers in these regions. A total of 651 composite soil samples were collected from small-scale farmers in several districts and among them Mazabuka district. Ninety per cent of the total soil samples from the districts sampled were found to have low to very low exchangeable magnesium and $49 \%$ very low exchangeable calcium. Soil samples from Eastern, Southern and Central Provinces were found to have medium to very high exchangeable potassium. It was strongly recommended that lime be considered as one of the major inputs in the farming system of the surveyed provinces. Inorganic fertilizer recommendations based on soil analysis were also given particularly for Central, Southern and some parts of Eastern Districts of Zambia [10]. Published research on heavy metals is lacking in these predominantly rural districts of Zambia. Most studies have focused on agriculture related elements; the common anions and cations.

\subsubsection{Lusaka City (Lusaka Province)}

From its earliest days of settlement in the early 1900s, the suitability of Lusaka city's location has been a source of great controversy, the major one having been hitherto the nature of the bedrock and the hydrogeological regime underlying the city. During the city's founding, it usually experienced periodic rises of the water table close to the ground surface, causing occasional flooding. There are many issues related to threats of water resources, one contentious issue being the sanitation provision in Lusaka which is unacceptably insufficient, as in most cities in sub-Saharan Africa: most people do not have access to a hygienic toilet; large amounts of faecal waste are discharged to the environment without adequate treatment. There are also large amounts of backyard dumpsites; this is likely to have major impacts on groundwater (and streams/rivers) considering the shallow geology of Lusaka. A variety of industries are concentrated in Lusaka city and disposal of the waste they generate is questionable. The Environmental Council of Zambia (ECZ) has no capacity to effectively monitor all the industries. On the other hand, abstraction of ground and surface water for householduse is common in Lusaka city; it was imperative to investigate the anthropogenic pollution due to dissolved metal pollution on the vast Lusaka water resources.

\subsubsection{Mufulira, Chingola, Kitwe, Ndola (Copperbelt Province)}

Streams and rivers are a major source of fresh water in Zambia. The Kafue River, for example, is a major supplier of fresh water to most residential areas in the Copperbelt region including the mining and chemical industries where large quantities of water are used to wash mineral ores in order to extract metals such as $\mathrm{Cu}$ and $\mathrm{Co}$. In the process, they generate effluents, which have potential to pollute the environment. The effluents are discharged into streams and rivers as a way of disposing them. The wastewaters (sometimespre-treated)are discharging to the surface waters of streams and reach ground waters through percolation and to the atmosphere by evaporation. Acid mine drainage, a condition created by effluents when disposed into stream and river waters, affects the water quality [11]. Water samples from four mining towns, their network of rivers and tributaries were collected and analysed for dissolved heavy metals.

\section{Method}

\subsection{Sampling Sites and Instrumentation}


The water samples were collected in September and October 2011. The following metals $\mathrm{As}, \mathrm{Cd}, \mathrm{Cu}$ and $\mathrm{Ni}$ were determined by the Varian 720-ES Inductively Coupled Plasma (ICP) optical emission spectrometer-model 720 ICPOES. The metals $\mathrm{Cr}, \mathrm{Mn}, \mathrm{Pb}$ and $\mathrm{Zn}$ were determined by a Perkin Elmer Analyst 100 Flame Atomic Absorption Spectrophotometer (AAS) using an air/acety- lene flame. The determination of $\mathrm{pH}$ and temperature was determined by As One 392R pH meter. Further interpretation of the data was done by spearman correlation ( $r$ ) and Principal Component Analysis (PCA) using SPSS statistical package version 17.0 (SPSS Inc., Chicago, III).

\subsection{Water Pollution Index (WPI)}

Part of the analysis involved use of the Nemerow- Sumitomo Water Pollution Index (WPI). The function of this method was to standardize the concentrations ranges for the parameters such that the different concentrations ranges for each water parameter were rescaled by the equation to produce a relative value that lies within a comparable range [12].

Based on chemical loadings relative to their permissible values $(P V s)$, the results from the water samples were classified into 4 categories. The classification used in this study reflects the suitability of the water for human consumption because only $P V$ s for drinking water were used. The $P V$ s utilised in this study are based on Zambia Bureau of Standards (ZBS). Utilizing the $P V$ s obtained from ZBS, the WPI was classified into four categories expressing the surface and groundwater pollution levels as categorised below.

$0.0 \leq W P I \leq 1.0=$ clean water (meets the $P V$ criteria)

$1.0>W P I \leq 5.0=$ slightly polluted water

$5.0>W P I \leq 10=$ moderately polluted water

$W P I>10=$ highly polluted water

\section{Data Analysis}

\subsection{Preliminary Analysis of the Raw Data}

Table 1 shows the parameters relative to their PVs. Arsenic is one parameterwhose maximum recordable value exceeded its recommended value in drinking water.

$\mathrm{Cd}$ on the other hand was undetectable in all the samples assessed in this study. In all the parameters assessed, the average values were far below their $P V$ s except for $\mathrm{Mn}$ and Ni. The other parameters whose maximum recordable values exceeded their permissible values were $\mathrm{Mn}, \mathrm{As}, \mathrm{Cr}, \mathrm{Ni}$, and $\mathrm{Pb}$.

\subsection{Statistical Treatment}

The communalities ranged from $88.7 \%$ for $\mathrm{Mn}$ to $25.8 \%$ for $\mathrm{Pb}$. Three factors were extracted by PCA. Analysis of the rotated matrix showed that Mn had the greatest in- fluence in this category (F1) and was associated with $\mathrm{Ni}$ Table 1. Summary of the pollution data obtained from 74 locations around Zambia.

\begin{tabular}{cccccc}
\hline Parameter & Min & Average & Max & $\begin{array}{c}\text { Permissible } \\
\text { Value }\end{array}$ & SD \\
\hline pH & 5.750 & 7.680 & 8.440 & $6.0-8.5$ & 0.429 \\
Temperature & 20.50 & 23.59 & 27.00 & & 1.42 \\
As (ppm) & 0.000 & 0.009 & 0.506 & 0.050 & 0.058 \\
Cd (ppm) & 0.000 & 0.000 & 0.000 & 0.005 & 0.000 \\
Cr (ppm) & 0.000 & 0.010 & 0.089 & 0.050 & 0.028 \\
Cu (ppm) & 0.000 & 0.012 & 0.270 & 1.000 & 0.037 \\
Mn (ppm) & 0.000 & 0.369 & 10.389 & 0.100 & 1.618 \\
Ni (ppm) & 0.000 & 0.015 & 0.698 & 0.010 & 0.083 \\
Pb (ppm) & 0.000 & 0.003 & 0.094 & 0.050 & 0.015 \\
Zn (ppm) & 0.000 & 0.075 & 1.210 & 5.000 & 0.206 \\
\hline
\end{tabular}

and $\mathrm{Cu}$. The second factor (F2) was dominated by $\mathrm{Zn}$ and associated with $\mathrm{Cr}$ and $\mathrm{Pb}$. The third factor (F3) only consisted ofAs. The factors extracted suggest that $\mathrm{Cu}, \mathrm{Ni}$ and Mn may have the same origin. This fact is further reinforced by the Pearson correlation which shows that $\mathrm{Mn}$ correlates strongly with $\mathrm{Cu}$ and $\mathrm{Ni}$. Cd, though analysed, was not included in thedata analysis because it was undetectable in all thewater samples from the 74 sites. Pollution due to three metals ( $\mathrm{Mn}, \mathrm{Ni}$, \& $\mathrm{Cu}$ ) explained $61.1 \%$ of the variance.

The WPI reveals that out of all the water collected from Lusaka city, $72 \%$ is not compromised (it's safe for human consumption); out of the water samples collected from the Copperbelt and North-western (the mining provinces), only $46 \%$ was safe for human consumption and none of the samples from southern and central revealed traces of heavy metal pollution. Overall, the Copperbelt region had the worst polluted water (by per cent of the water which meet the clean water criteria).

\subsection{Pattern of the Pollution}

Despite the widespread $\mathrm{Cu}$ mining activities in Zambia, there were no significant levels of dissolved $\mathrm{Cu}$ in all the regions that were sampled. However, there was significant pollution due to Mn as shown in Table 1. Mn pollution was also a major pollution factor even in Lusaka even though it is not a mining city; surface water was more polluted compared to groundwater. The ground water collected near high density residential areas with a rudimentary sewer system and with widespread use of on-site sanitation and ahigh prevalence of backyard dumpsites did not prove to have any serious heavy metal loadings beyond what is permissible in drinking water. Kabwe is reported as one of the most polluted towns in 
Zambia but the water collected from the domestic water taps met the drinking water criteria with pollution indexes of 0.07 and 0.05 . The heavy metal pollution in the former mining giant exist in form of dust and pollution in soils and sediments, and in the vicinity of the former mine [5]. Dissolved heavy metal pollution was not a huge factor in the former mining town (Kabwe) even though it ranks amongst the top ten most polluted areas in the world.

\section{Discussion}

Analysis of the water from the Copperbelt revealed that surface or river/stream water was polluted the most as judged by the WPI. As expected there was more pollution near the mine effluent and a progressive reduction downstream. The previous study of ground water pollution on the geological and geochemical investigation strongly suggests an upslope tailings impoundment as the source of contaminants with the edge of the pollution plume lying 500 - $700 \mathrm{~m}$ downstream of the impoundment. Furthermore, it was found that there was attenuation of heavy metals as linked to tailings dam and aquifer $\mathrm{pH}$, with the high buffering capacity of each implying that these processes of attenuation are likely to continue removing harmful metals from the aquifer[7]. In this studysimilar water samples were collected near tailings impoundments and they had pollution indexes of 5.21 and 8.09. However, it was found that dissolved metal concentration was particularly high near the effluent water from the tailings dump. Mulonga water and sewerage company-Mufulira town obtains its water from Kafue River with WPI of 0.82 and after treatment, the WPIwas 0.02. This shows that water treatment is effective and the water supplied to former council residential areas is safe. However, the scenario is different with the water supplied to the former mine residential areas which had the WPI of 4.26. This water is obtained from the copper mine ground aquifer. Its WPI is classified as slightly polluted water under the scale chosen in this study and may not be suitable for long term use for human consumption.

\subsection{Description of the Pollution by Parameter}

\subsubsection{Arsenic (As)}

Drinking water especially that derived from boreholes/wells is a major source of As for many people. Although anthropogenic uses of As can result in its contamination of water, by far the greatest problems occur with that produced by natural processes [13]. One sample out of the 74 samples, tested for As loadings to pollution levels; the pollution index was 5.17. The water that was sampled from this site is in a vicinity of a large illegal dumpsite. However, all the other ground and surface wa- ter samples were free of As loadings to pollution levels.

\subsubsection{Copper (Cu)}

The study did not find significant amounts of dissolved $\mathrm{Cu}$ in water, notwithstanding the limitation of the study that it did not concentrate on total heavy metal pollution. All the samples met the clean water criteria both in the Copperbelt Province, Lusaka city and the other regions assessed in this study.

\subsubsection{Zinc (Zn)}

Some common examples of the use of zinc compounds in Zambia include: zinc oxide used as a white pigment, zinc chromate used as a rust inhibitor; zinc chloride used as an electrolyte in dry-cell batteries; rubber and plastic compositions (these are usually discarded in illegal dumpsites/landfills after their useful lifespan); zinc oxide and zinc chloride used for vulcanising rubber and as pigments and fillers, especially in vehicle tyres; zinc sulphate used in paper bleaching; insecticides and fungicides as zinc naphthenate, zinc octoate, zinc versatate used to preserve wood against fungal rot and insects; zinc phosphide used in rodent bait. However, despite its versatility, the highest $\mathrm{Zn}$ load determined was $1.21 \mathrm{ppm}$. The site with the highest $\mathrm{Zn}$ loads was a ground water sample in the mining town of Mufulira but not any closer to obvious sources of pollution. However, it was still within safe drinking levels of $5 \mathrm{ppm}$ as stipulated by Zambia Bureau of standards.

\subsubsection{Chromium (Cr)}

In trace amounts, $\mathrm{Cr}$ is considered an essential nutrient for numerous organisms $[15,16]$ but at higher level, it is toxic and mutagenic [17]. Chrome tanning processes are popular at industrial scale and discharge of untreated wastewater into the environment a commonplace. In such aqueous waste, $\mathrm{Cr}$ (VI) is present as either dichromate $\left(\mathrm{Cr}_{2} \mathrm{O}_{7}{ }^{2-}\right)$ in acidic environments or as chromate $\left(\mathrm{CrO}_{4}^{-}\right)$ in alkaline environments [14]. In this study, $\mathrm{Cr}$ was strongly associated with $\mathrm{Zn}$ and $\mathrm{Pb}$ in the PCA and significantly correlated with $\mathrm{Ni}(\mathrm{r}=.305, \mathrm{p}<0.05,2$ tailed). However, the average concentration of $\operatorname{Cr}(0.01 \mathrm{ppm})$ was far below its $P V$ of $0.05 \mathrm{ppm}$. Cr was not deemed a serious pollution problem in the study areas.

\subsubsection{Manganese (Mn)}

Environmental pollution seems to have an independent effect on the rate of violent crimes - defined as homicide, aggravated assault, sexual assault and robbery [18]. It is argued that counties with the highest levels of $\mathrm{Pb}$ and $\mathrm{Mn}$ pollution typically have crime rates three times the national average. Mn was the biggest pollution problem determined in the Copperbelt region and Lusaka city. Could this be a possible explanation of high crime rates 
reported in these regions notwithstanding the other causes of crime such as poverty (subject to further research)? The average Mn pollution was $0.37 \mathrm{ppm}$ well beyond the $P V$ of $0.10 \mathrm{ppm}$. The site with the highest $\mathrm{Mn}$ level was 100 times the $P V$ for drinking water. It is worth noting that high levels of $\mathrm{Mn}$ and $\mathrm{Cu}$ pollution in urban areas are linked to increased risk of Parkinson's disease, according to a large-scale analysis of urban pollution and Parkinson's incidence in the United States [19].

\subsubsection{Nickel (Ni)}

From PCA analysis and Pearson correlation analysis, the results show that $\mathrm{Ni}$ strongly correlated with $\mathrm{Mn}(r$ $=.676, p<0.01,2$ tailed), which is also the single most significant pollution problem in Zambia. It was detectable in the Zambian water samples beyond the recommendable value of $0.01 \mathrm{ppm}$; the maximum value registered was $0.70 \mathrm{ppm}$.

\subsubsection{Lead (Pb)}

In the absence of any recycling of $\mathrm{Pb}$-acid batteries and other $\mathrm{Pb}$ containing products in Zambia, it can be assumed that $\mathrm{Pb}$-acid batteries contribute a high percentage of $\mathrm{Pb}$ pollution in the municipal solid waste. $\mathrm{Pb}$ in petrol used in Zambia was only phased out in March 2008. Because of the persistent nature of heavy metal in the soil, it was expected that groundwater would test for $\mathrm{Pb}$.

Through plant uptake, $\mathrm{Pb}$ enters food chains. It is argued that $\mathrm{Pb}^{2+}$, being similar to $\mathrm{Ca}^{2+}$, gets accumulated in the bones and is subsequently remobilised along with phosphates from bones which exert a toxic effect [20]. Analysis of correlation coefficient revealed that levels of $\mathrm{Pb}$ did not correlate with any other metal. The average concentration was $0.003 \mathrm{ppm}$, well below the $P V$ value of $0.05 \mathrm{ppm}$. The highest concentration determined being $0.094 \mathrm{ppm}$. Despite the numerous reports documenting the historical negative effects of the obsolete Kabwe mine on the environment, dissolved $\mathrm{Pb}$ pollution was not beyond the recommended $P V$ in all the samples except two sites, onein the Copperbelt region and the other in Lusaka city. The samples from the former, and only $\mathrm{Pb}$ mining town, were free of any $\mathrm{Pb}$ contamination.

\section{Conclusion}

Contrary to popular belief and what other researchers may have reported about Zambia that soil sediments are contaminated with heavy metals. This study found no apparent serious problems, involving all heavy metals, which can be considered as being beyond remediation. There were no significant metal loadings in high density informal settlements and near illegal or backyard dumpsites. The heavy metal pollution problems are to a large extent confined to the mining towns and are mostly due to Mn. Even though Zambia is a mining country and the seventh producer of refined $\mathrm{Cu}$ as of 2010 [21], the pollution due to dissolved $\mathrm{Cu}$ is insignificant even from the effluent water discharged by the mines in Mufulira and Chingola towns. The high levels of heavy metal, especially $\mathrm{Mn}$, loads in the Copperbelt are a probable consequence of the lack of control and remediation measures during and after mining operations. Factor 1, using PCA, showed that Mn was the most influential factor explaining 30.4 per cent of variance observed in the analysis. The statistical analysis further revealed that Mn correlates positively and significantly with $\mathrm{Cu}$ and $\mathrm{Ni}$. Despite environmental protection legislation and monitoring by ECZ and other controlling bodies being in existence, the mining industry is the main source of the observed water pollution and especially Mn. On the other hand, Nchanga tailings leach plant in Chingola manages a $\mathrm{Cu}$ tailings leach plant. The processes range from reclamation, concentrator tails, thickening/dewatering, filtration, leaching, concentration in counter current decantation thickeners, purification in solvent extraction/electro winning and neutralization of final tails with lime from the lime plant. Despite all these processes the $\mathrm{pH}$ did not show any anomalies not only from the Nchanga mine or the Mufulira mine effluent with similar operations, but all samples across Zambia except for one sample from Lusaka city which was slightly acidic at $\mathrm{pH} 5.75$.

\section{Acknowledgement}

The authors would like to earnestly express their gratitude to the Global Environmental Leaders (GEL) program of Hiroshima University for the generous financial support.

\section{REFERENCES}

[1] Ministry of Mines and Minerals Development, "Mining in Zambia,"n.d..

http://www.zambiamining.co.zm/industrialminerals.htm

[2] K. C. Choongo, M. S. Syakalima and M. Mwase, "Coefficient of Condition in Relation to Copper Levels in Muscle of Serranochromis Fish and Sediment from the Kafue River, Zambia,"Bulletin of Environmental Contamination and Toxicology, Vol.75, No. 4, 2005, pp. 645-651. doi:10.1007/s00128-005-0801-1

[3] J. Holden, "How do the public and policy makers communicate their perceptions of environmental risk to academics?”Geophysical Research Abstracts, Vol. 12, 2010, EGU2010-15422.

http://meetingorganizer.copernicus.org/EGU2010/EGU20 10-15422.pdf

[4] I. Sherameti andA.Varma, "Soil Heavy Metals,” Springer, 2009.

[5] B. D. Tembo, K. Sichilongoand J. Cernak, "Distribution 
of copper, lead, cadmium and zinc concentrations in soils around Kabwe town in Zambia,"Chemosphere, Vol. 63, No. 3,2006, pp. 497-501.

doi:10.1016/j.chemosphere.2005.08.002

[6] WHO (2011). Global task force on cholera control. Cholera country profile: Zambia. Retrieved from http://www.who.int/cholera/countries/ZambiaCountryPro file2011.pdf

[7] C. J. von der Heyden andM. G. New, Groundwater pollution on the Zambian Copperbelt: deciphering the source and the risk. Science of The Total Environment, Vol. 327, No.1-3, 2004, pp.17-30. doi:10.1016/j.scitotenv.2003.08.028

[8] Central Statistical Office, "2010 census of Pollution and Housing - Republic of Zambia,” 2011. http://unstats.un.org/unsd/demographic/sources/census/20 10_phc/Zambia/PreliminaryReport.pdf

[9] ZARI, "Soil Fertility Research: Critical levels of Zinc in Intensive Agriculture,” n.d..

http:// www.zari.gov.zm/soil_fertility_research.ph

[10] F. W. NtengweandK. K. Maseka, "The impact of effluents containing zinc and nickel metals on stream and river water bodies: The case of Chambishi and Mwambashi streams in Zambia,"Physics and Chemistry of the Earth, Parts A/B/C, Vol. 31 No.15-16, 2006, pp. 814-820.doi:10.1016/j.pce.2006.08.027

[11] N. L. Nemerow, and H. Sumitomo, "Benefits of Water Quality Enhancement,” Report No 16110 DAJ, prepared for the US Protection Agency. Syracuse University, Syracuse, NY, 1970.

[12] C. BairdandM. Cann, "Environmental Chemistry," 4th edition, W. H. Freeman, 2008.

[13] S. Yadav, O. P. Shuklaand U.N. Rai, "Chromium pollution and bioremediation,"Environews Newsletter of ISEB India, Vol. 11, No. 1, 2005.

[14] W. Mertz, “The essential trace elements,”Science, Vol. 213, No. 4514, 1981, pp. 1332-1338. doi:10.1126/science.7022654

[15] A. Pechova andL. Pavlata, "Chromium as an essential nutrient: a review,”Veterinarni Medicina, Vol. 52, No. 1, 2007, pp. 1-18.

[16] M. Cieslak-Golonka, "Toxic and Mutagenic Effects of Chromium(VI). A Review,”Polyhedron, Vol. 15, No. 21, 1996, pp. 3667-3689.

[17] A. Motluk, "Lead and Manganese Pollution may Lead to a Life of Crime,”LEAD Action News, Vol. 5, No. 3, 1997.

[18] SustainableBusiness.com News., "Manganese, Copper Pollution Linked to Parkinson's disease,” 2010. http://www.sustainablebusiness.com/index.cfm/go/news.d isplay/id/21358

[19] V. K. AhluwaliaandS. Malhotra, "Environmental Science,” Boca Raton: CRC, 2007.

[20] British Geology Survey, "World Mineral Production, 2006-10,” Keyworth, Nottingham: British Geological Survey, 2012 